\title{
A FAST AND SENSITIVE ZYMOGRAPHY METHOD OF PEROXIDASE ACTIVITY DETERMINATION USING SODIUM ACETATE BUFFER
}

\author{
GHEORGHITA MENGHIU, \\ AMALIA NICOLETA IANCU ${ }^{\mathrm{a}, \mathrm{b}}$ AND VASILE OSTAFE, ${ }^{\mathrm{a}, \mathrm{b}}$ *
}

\begin{abstract}
By changing the buffer composition from phosphate to acetate (in both cases, the pH value was 6.0), the sensitivity of the estimation of peroxidase activity in polyacrylamide gels was improved from $4 \mu \mathrm{g} / \mathrm{well}$ to $0.4 \mu \mathrm{g} /$ well. The optimized method, including electrophoretic separation and zymogram technique realized with guaiacol as substrate, can be performed in only 135 minutes. The improved method was applied to monitor the expression of recombinant peroxidase in a Gram-negative bacterium: the peroxidase activity was detected at $4 \mathrm{~h}$ after induction of expression.
\end{abstract}

Keywords: zymography, peroxidase, guaiacol, SDS-PAGE

\section{INTRODUCTION}

There are many circumstances when the presence, the purity or even the quantity of a protein in a solution is evaluated by polyacrylamide gel electrophoresis (PAGE) [1-3]. When the analyzed protein is an enzyme, its activity can be estimated combining electrophoretic separation with zymogram [4]. For example, the activity of peroxidase can be analyzed directly on the gel by addition of a suitable substrate, like guaiacol [5]. After the electrophoretic separation, the gels are basically incubated in the substrate solution which will reveal as brownish bands on the translucent gel only those protein bands

\footnotetext{
a West University of Timisoara, Faculty of Chemistry, Biology, Geography, Department of Biology - Chemistry, 16 Pestalozzi, 300115 Timisoara, Romania

b West University of Timisoara, Multidisciplinary Research Platform "Nicholas Georgescu Roengen", Advanced Environmental Research Laboratory, 4 Oituz, 300086, Timisoara, Romania

* Corresponding author: vasile.ostafe@e-uvt.ro
} 
that have enzymatic activity. Next, the same gel is colored with Coomassie brilliant blue that will stain all proteins bands separated on that gel $[6,7]$. In majority of the cases, the quantity of the enzyme of interest is very low and the sensitivity of the analytical method becomes an important parameter. This can be the case, when the enzyme of interest is heterologous expressed in an appropriate microorganism and the evolution of expression of studied enzyme should be monitored $[8,9]$. In this paper we have succeeded to optimize the electrophoretic separation coupled with zymogram identification of peroxidase, performing the analytical method in only $135 \mathrm{~min}$ with a detection limit of only $0.4 \mu \mathrm{g}$ peroxidase/well. As far as we know, the lowest reported sensitivity of a zymogram based on guaiacol for peroxidase was $4 \mu \mathrm{g}$ peroxidase/well [10].

\section{RESULTS AND DISCUSSION}

The 2-methoxyphenol (guaiacol) compound is used in this work as a hydrogen donor substrate in the zymogram assay of the peroxidase. Upon oxidation, it forms tetraguaiacol (Figure 1), a brownish product with maximum absorbance at $470 \mathrm{~nm}$ and an extinction coefficient of $26.6 \mathrm{mM}^{-1} \mathrm{~cm}^{-1}$ [11].
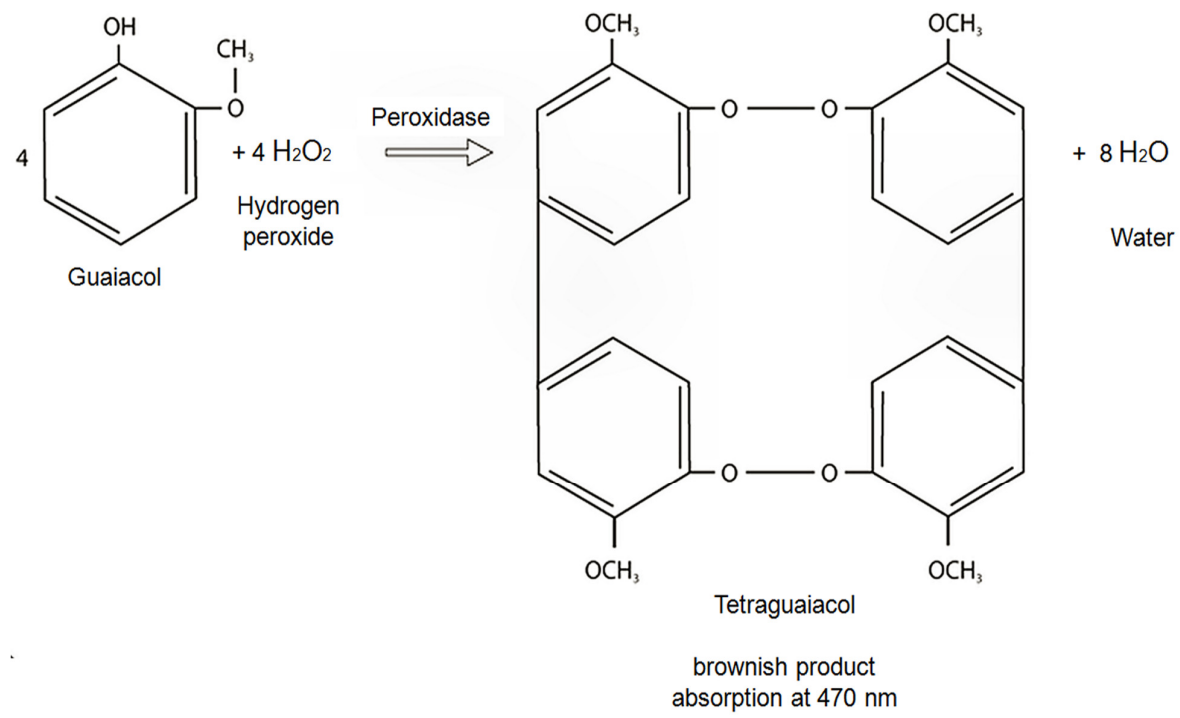

Figure 1. Schematic reaction of peroxidase on $\mathrm{H}_{2} \mathrm{O}_{2}$ and guaiacol substrates 


\section{A FAST AND SENSITIVE ZYMOGRAPHY METHOD OF PEROXIDASE ACTIVITY DETERMINATION USING SODIUM ACETATE BUFFER}

In Figure 2 is showed the standard SDS-PAGE analysis of different amounts of a commercial horseradish peroxidase $(0.05,0.1,0.2,0.4,0.8$, $1.2,1.6, .2 .0,2.4,2.8,3.2$, and $3.6 \mu \mathrm{g} /$ well, under reducing conditions, stained with Coomassie brilliant blue G-250. The sensitivity of the method in the experimental condition is $0.1 \mu \mathrm{g}$ protein/well (Figure 2, lane 2). To reveal the activity of the peroxidase directly on the polyacrylamide gel a zymogram, using guaiacol as substrate, was realized.

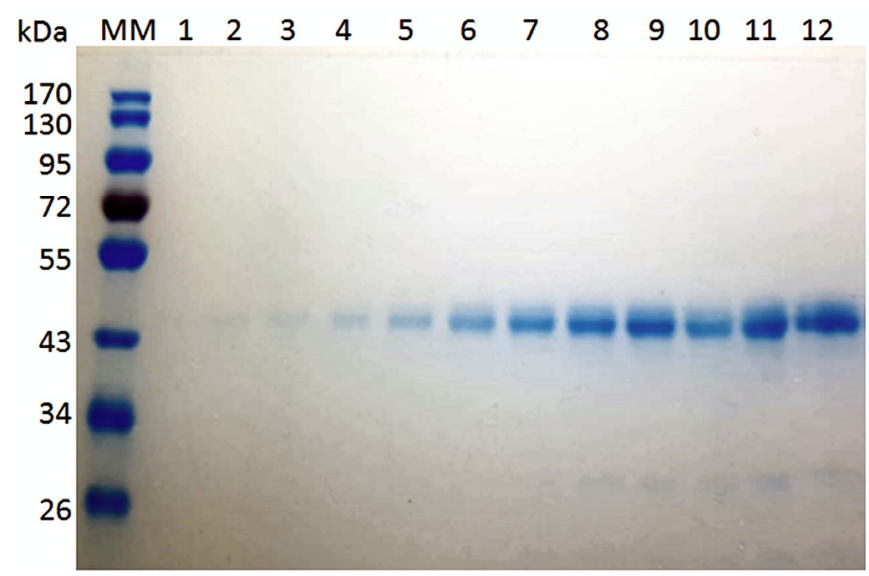

Figure 2. SDS-PAGE analysis ( $10 \%$ gel) of commercial horseradish peroxidase, under reducing conditions. $\mathrm{MM}=$ protein molecular marker $(\mathrm{kDa})$. Lanes 1-12, different amounts of commercial peroxidase: lane $1=0.05 \mu \mathrm{g}$, lane $2=0.1 \mu \mathrm{g}$, lane $3=0.2 \mu \mathrm{g}$, lane $4=0.4 \mu \mathrm{g}$, lane $5=0.8 \mu \mathrm{g}$, lane $6=1.2 \mu \mathrm{g}$, lane $7=1.6 \mu \mathrm{g}$, lane $8=2.0 \mu \mathrm{g}$, lane $9=2.4 \mu \mathrm{g}$, lane $10=2.8 \mu \mathrm{g}$, lane $11=3.2 \mu \mathrm{g}$, lane $12=3.6 \mu \mathrm{g}$.

The majority of published techniques for zymogram of peroxidase, using guaiacol as substrate, recommended to use phosphate buffer at $\mathrm{pH}$ 7.0 [10]. In these conditions, the sensitivity of the reported method was as low as $4 \mu \mathrm{g}$ protein/well.

Using phosphate buffer (at three $\mathrm{pH}$ values) we have analyzed the sensitivity of methods regarding the identification of peroxidase based on zymogram with guaiacol and identification of protein colored with Coomassie Blue (Figure 3). Although the identification of proteins was as sensitive as $0.1 \mu \mathrm{g}$ total protein/well, the identification of peroxidase had a sensitivity of only $2 \mu \mathrm{g}$ total protein/well. It is not the scope of this work to explain why the commercial peroxidase used in these experiments have revealed 3 bands of proteins and 2 bands with peroxidase activity. In the absence of other experiments or information provided by the producer, we can hypothesize that the commercial peroxidase is not a pure product, but contains some 
isoenzymes and, perhaps, another protein added as stabilizer (perhaps ovalbumin) [12-14]. What is important to consider from Figure 3 is that the sensitivity of zymogram technique is limited at $2 \mu \mathrm{g}$ protein/well. Our interest was to study the expression of peroxidase in a bacterial expression system (data presented in another paper) and the needed sensitivity requested by the experiment was at least $0.5 \mu \mathrm{g}$ peroxidase/well. This is the reason we have considered to change some of the parameters of the zymogram methods.

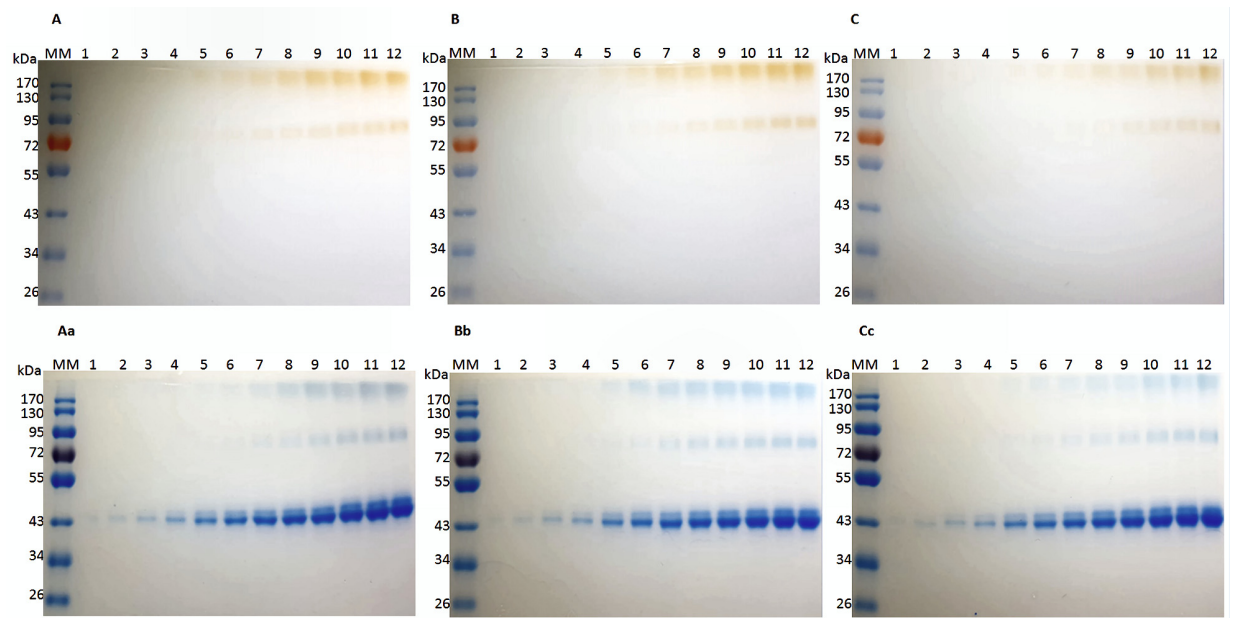

Figure 3. Zymogram analysis of commercial horseradish peroxidase under nonreducing conditions $(\mathrm{A}, \mathrm{B}, \mathrm{C})$ using $0.1 \mathrm{M}$ sodium phosphate buffer $\mathrm{pH} 5(\mathrm{~A}), \mathrm{pH}$ 6 (B), pH 7 (C), $\mathrm{H}_{2} \mathrm{O}_{2}$ and guaiacol substrates. SDS-PAGE analysis ( $\left.10 \% \mathrm{gel}\right)$ of commercial horseradish peroxidase, under non-reducing conditions ( $\mathrm{Aa}, \mathrm{Bb}, \mathrm{Cc}$ ). The gels were stained with guaiacol and after that with Coomassie brilliant blue G-250. $\mathrm{MM}=$ protein molecular markers. Lanes 1-12, different amounts of commercial peroxidase: lane $1=0.05 \mu \mathrm{g}$, lane $2=0.1 \mu \mathrm{g}$, lane $3=0.2 \mu \mathrm{g}$, lane $4=0.4 \mu \mathrm{g}$, lane $5=0.8 \mu \mathrm{g}$, lane $6=1.2 \mu \mathrm{g}$, lane $7=1.6 \mu \mathrm{g}$, lane $8=2.0 \mu \mathrm{g}$, lane $9=2.4 \mu \mathrm{q}$. lane $10=2.8 \mu \mathrm{q}$. lane $11=3.2 \mu \mathrm{q}$, lane $12=3.6 \mu \mathrm{q}$.

After testing several buffers compositions, we concluded that the best results are obtained using $0.1 \mathrm{M}$ sodium acetate, $\mathrm{pH} 6.0$ (Figure 4). For the reason of comparison with Figure 3, in Figure 4 are presented the zymograms and protein staining images, realized in acetate buffer at pH 5.0, 6.0 and 7.0 respectively. At pH 5.0 and 6.0 , in this buffer, activity of $0.4 \mu \mathrm{g}$ of peroxidase is visible on the gel (Figure $4 \mathrm{~A}$ and $\mathrm{B}$, lane 4). At pH 7.0 only one brownish line of bands can be detected, i.e. only one isoenzyme is active at this $\mathrm{pH}$, and the minimum amount detected was $0.8 \mu \mathrm{g}$ enzyme/well (Figure $4, \mathrm{C}$, lane 5). 


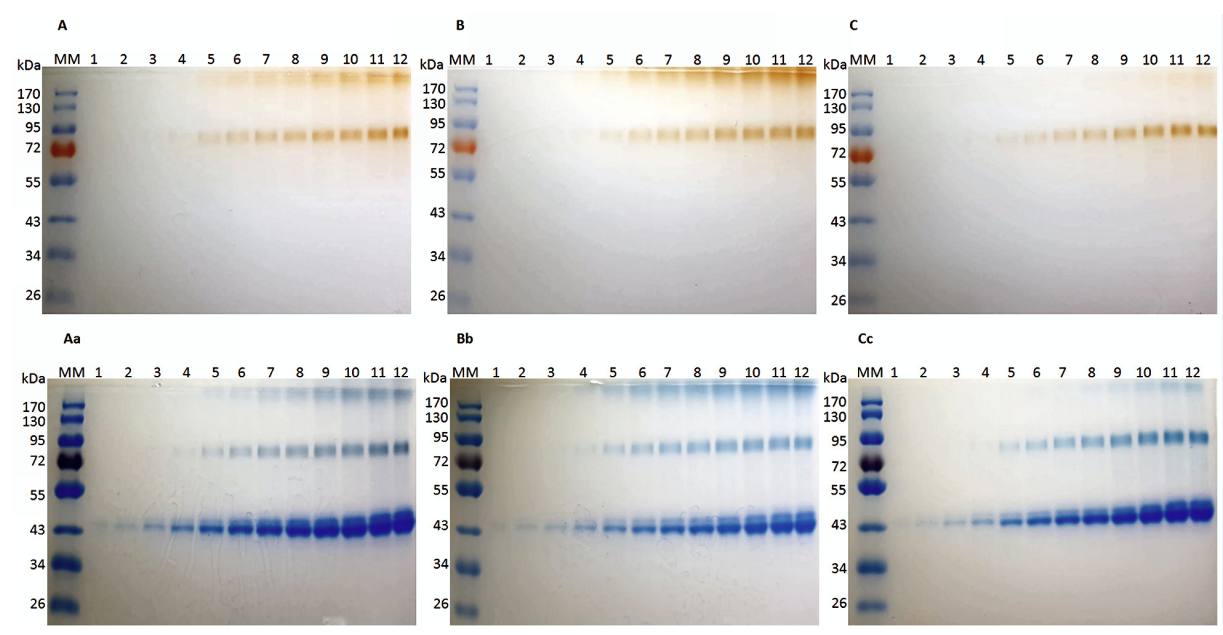

Figure 4. Zymogram analysis of commercial horseradish peroxidase under nonreducing conditions $(\mathrm{A}, \mathrm{B}, \mathrm{C})$ using $0.1 \mathrm{M}$ sodium acetate buffer $\mathrm{pH} 5(\mathrm{~A}), \mathrm{pH} 6$ (B), $\mathrm{pH} 7$ (C), $\mathrm{H}_{2} \mathrm{O}_{2}$ and guaiacol substrate. SDS-PAGE analysis (10\% gel) of commercial horseradish peroxidase, under non-reducing conditions $(\mathrm{Aa}, \mathrm{Bb}$, Cc). The gels were stained with guaiacol and then with CBB G-250. MM = protein molecular markers. Lanes 1-12, different amounts of commercial peroxidase: lane $1=0.05 \mu \mathrm{g}$, lane $2=0.1 \mu \mathrm{g}$, lane $3=0.2 \mu \mathrm{g}$, lane $4=0.4 \mu \mathrm{g}$, lane $5=0.8$ $\mu \mathrm{g}$, lane $6=1.2 \mu \mathrm{g}$, lane $7=1.6 \mu \mathrm{g}$, lane $8=2.0 \mu \mathrm{g}$, lane $9=2.4 \mu \mathrm{g}$, lane $10=$ $2.8 \mu \mathrm{g}$, lane $11=3.2 \mu \mathrm{g}$, lane $12=3.6 \mu \mathrm{g}$.

The method for identification of peroxidase using guaiacol as substrate, in acetate buffer, can be realized in only 135 minutes: 90 minutes electrophoretic run, 30 min incubation in reactivation buffer (acetate, containing Triton X100) and 15 min in substrate solution. This improved method of estimation of peroxidase activity in PAGE was very useful for evaluation of peroxidase expression in a Gram-negative bacterium (the experiments will be published in another paper). Figure 5 is presented only as proof that the improved zymogram protocol can be applied to solve some concrete problems from biochemistry laboratories.

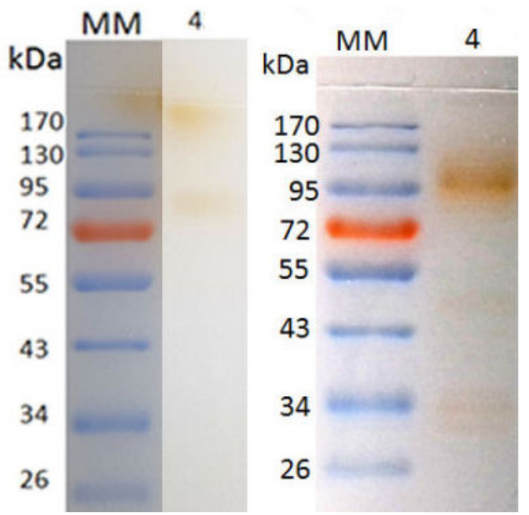

Figure 5. Zymogram analysis of recombinant peroxidase expressed in a Gram-negative bacterium. Left panel - zymogram realized in phosphate buffer, $\mathrm{pH}$ 6.0; right panel zymogram realized in acetate buffer, $\mathrm{pH} 6.0$, in both cases after $4 \mathrm{~h}$ after addition of expression inductor. 


\section{CONCLUSIONS}

An improved method for estimation of peroxidase activity in PAGE capable to reveal quantity of peroxidase activity as low as $0.4 \mu \mathrm{g} / \mathrm{well}$ was realized by performing the enzymatic reaction in acetate buffer, $\mathrm{pH} 6.0$ using guaiacol as substrate. The applicability of the method was tested on real samples.

\section{EXPERIMENTAL SECTION}

\section{Chemicals, enzymes and instruments}

All chemicals were bought from Carl Roth and Sigma-Aldrich, Germany unless otherwise stated. The horseradish peroxidase was purchased from SigmaAldrich, Germany as well. The Mini-Protean electrophoresis system was acquired from Bio-Rad Laboratories, USA.

\section{Buffer solutions}

Sodium acetate and sodium phosphate buffers were prepared, both having an ionic strength of $0.1 \mathrm{M}$ and three different $\mathrm{pH} 5.0,6.0$ and 7.0, respectively. The $\mathrm{pH}$ of sodium acetate buffer was adjusted with acetic acid or sodium hydroxide solution. The sodium phosphate buffer was prepared by mixing different volumes of $1 \mathrm{M} \mathrm{NaH}_{2} \mathrm{PO}_{4}$ and $1 \mathrm{M} \mathrm{Na}_{2} \mathrm{HPO}_{4}$ stock solutions to obtain three different $\mathrm{pH}$ values: 5.0, 6.0 and 7.0, respectively. Phosphoric acid was used to adjust $\mathrm{pH}$ to 5.0.

\section{Zymogram analysis solutions}

The reactivation solution consisted of $1 \%$ Triton $\mathrm{X} 100$ dissolved in each buffer solution at each $\mathrm{pH}$ value [10]. For substrate solutions, $10 \mu \mathrm{L}$ of $25 \%$ guaiacol $(\mathrm{v} / \mathrm{v})$ stock solution were mixed with $1.5 \mathrm{~mL}$ of $99.8 \%$ ethanol and finally $17.49 \mathrm{~mL}$ of each buffer were added. Before use, every substrate solution was supplemented with $1 \mathrm{~mL}$ of $0.3 \% \mathrm{H}_{2} \mathrm{O}_{2}$ solution.

\section{Sodium dodecyl sulphate polyacrylamide gel electrophoresis (SDS-PAGE)}

SDS-PAGE analysis was modified after Laemmli protocol [15]. Separation gels with $0.75 \mathrm{~mm}$ thickness, with $10 \%$ acrylamide concentration were prepared.

The samples were prepared under reducing conditions $(250 \mathrm{mM}$ Tris- $\mathrm{HCl}$ $\mathrm{pH} 6.8,25 \%(\mathrm{v} / \mathrm{v})$ glycerol, $10 \%(\mathrm{w} / \mathrm{v})$ SDS, $1 \mathrm{M}$ 2-mercaptoethanol, $0.05 \%(\mathrm{w} / \mathrm{v})$ bromphenol blue) and non-reducing conditions (62.5 mM Tris-HCl, pH 6.8, 1\% (w/v) bromophenol blue, $25 \%$ (v/v) glycerol). A volume of $200 \mu \mathrm{L}$ of commercial horseradish peroxidase solution $(1 \mathrm{mg} / \mathrm{mL}$ ) was mixed with $200 \mu \mathrm{L}$ of non-reducing buffer and $100 \mu \mathrm{L}$ of $50 \%(\mathrm{v} / \mathrm{v})$ extra glycerol and incubated $10 \mathrm{~min}$ at room temperature. Similarly, were processed the samples from expression of peroxidase in Gram-negative 


\section{A FAST AND SENSITIVE ZYMOGRAPHY METHOD OF PEROXIDASE ACTIVITY DETERMINATION USING SODIUM ACETATE BUFFER}

bacteria. The reducing samples were similarly prepared, in a smaller volume, with $10 \mathrm{~min}$ boiling. The following amounts of commercial horseradish peroxidase: $0.05,0.1,0.2$, $0.4,0.8,1.2,1.6,2.0,2.4,2.8,3.2$, and $3.6 \mu \mathrm{g} /$ well were loaded. The electrophoresis was performed at $120 \mathrm{~V}$ in $1 \times$ SDS-running buffer (25 mM Tris, $0.19 \mathrm{M}$ glycine, $0.1 \%$ $(\mathrm{w} / \mathrm{v}) \mathrm{SDS}$ ) at room temperature, for 90 minutes.

\section{Zymogram analysis}

After electrophoresis, the gels were washed with distilled water and incubated in reactivation solutions for $30 \mathrm{~min}$, under gentle shaking. The gels were again washed few times and incubated for $15 \mathrm{~min}$, under gentle shaking, in guaiacol substrate solutions containing hydrogen peroxide made in different buffers and different $\mathrm{pHs}$. The gels were photographed and after, the protein bands were colored with Coomassie brilliant blue G250.

\section{Coomassie brilliant blue (CBB) G-250 gels staining and distaining}

Gels were stained, and the proteins were fixed in a solution $(A)$ containing 25\% (v/v) 2-propanol, 10\% (v/v) acetic acid and 0.05\% (w/v) CBB G-250. The mixture was heated until boiling (approx. $30 \mathrm{~s}$ ) in the microwave oven then the gels were gentle shake for $30 \mathrm{~min}$. The gels were washed with distillated water and immersed in solutions (B) containing 10\% (v/v) 2-propanol and 0.05\% (w/v) CBB G-250, and (C) containing $10 \%(\mathrm{v} / \mathrm{v})$ acetic acid and $0.002 \%(\mathrm{w} / \mathrm{v})$ CBB G-250. In each solution the gels were microwaved $30 \mathrm{~s}$ and immediately washed. The destaining step of the gels was performed in $10 \%(\mathrm{v} / \mathrm{v})$ acetic acid solution and after 1 min of microwaving, a paper towel was added to the reaction vessel, under gentle shaking, for 20 minutes [16].

\section{ACKNOWLEDGMENTS}

G. Menghiu acknowledges that this work was supported by the strategic grant POSDRU/159/1.5/S/137750, Project "Doctoral and Postdoctoral programs support for increased competitiveness in Exact Sciences research". The authors also acknowledge the GRANT PNIII-P3-284, ChitoWound - Biotechnological tools implementation for new wound healing applications of byproducts from the crustacean seafood processing industry.

\section{REFERENCES}

1. Rodriguez-Rubio, L., D.M. Donovan, B. Martinez, A. Rodriguez, and P. Garcia, Methods Mol Biol, 2019, 1898, 107-115.

2. Humer, D. and O. Spadiut, Int J Mol Sci, 2019, 20.

3. Krainer, F.W. and A. Glieder, Appl Microbiol Biot, 2015, 99, 1611-1625.

4. Leber, T.M. and F.R. Balkwill, Anal Biochem, 1997, 249, 24-28.

5. Achar, R.R., B.K. Venkatesh, P. Sharanappa, B.S. Priya, and S.N. Swamy, Appl Biochem Biotech, 2014, 173, 1955-1962. 
6. Castro, D., L.M. Contreras, L. Kurz, and J. Wilkesman, Methods Mol Biol, 2017, 1626, 199-204.

7. Şişecioğlu, M., I. Gülçin, M. Cankaya, A. Atasever, M. Hilal Şehitoğlu, H. Budak Kaya, and H. Özdemir, J Med Plants Res, 2010, 4, 1187-1196.

8. Pekarsky, A., L. Veiter, V. Rajamanickam, C. Herwig, C. Grunwald-Gruber, F. Altmann, and O. Spadiut, Microb Cell Fact, 2018, 17, 183.

9. Gundinger, T. and O. Spadiut, J Biotechnol, 2017, 248, 15-24.

10. Wilkesman, J., D. Castro, L.M. Contreras, and L. Kurz, Biochem Mol Biol Edu, 2014, 42, 420-426.

11. Uarrota, V.G., R. Moresco, E.C. Schmidt, Z.L. Bouzon, E. Da Costa Nunes, E. De Oliveira Neubert, L.A.M. Peruch, M. Rocha, and M. Maraschin, Food Chem, 2016, 197, 737-746.

12. Näätsaari, L., F.W. Krainer, M. Schubert, A. Glieder, and G.G. Thallinger, BMC Genomics, 2014, 15, 227-227.

13. Liu, E.H. and D.M. Gibson, Anal Biochem, 1977, 79, 597-601.

14. Wang, W., Protein Sci, 2015, 24, 1031-1039.

15. Laemmli, U.K., Nature, 1970, 227, 680-685.

16. Gușă, M.E., G. Menghiu, and V. Ostafe, New Front Chem, 2016, 25, 115-124. 